\title{
Teachers' Factor and Academic Performance of Primary Two Pupils with Attention Deficit Hyperactivity Disorder (ADHD) in Uyo Local Government Area of Akwa Ibom State, Nigeria

\author{
Olota , Philip Olaoluwa
} \\ Department of Early Childhood Education, Faculty of Education, University of Uyo, Uyo, Akwa Ibom state Email: eaglestutors@yahoo.com
}

\author{
Doi:10.5901/jesr.2016.v6n2p91
}

\section{Abstract}

The research investigated the teachers' factors and academic performance of primary 2 pupils with Attention Deficit Hyperactivity Disorder (ADHD) in private schools in Uyo Local Government Area of Akwa Ibom State, Nigeria. In order to achieve the objectives of the study two hypotheses were formulated and tested. The sample consisted of 8 teachers and 92 primary 2 pupils with ADHD. These subjects were randomly selected from 8 out of the 80 existing private primary schools in Uyo Local Government Area. A researcher-developed instrument, ADHD checklist and an achievement test were used for gathering data for the study. The checklist and achievement tests were duly validated by experts and subjected to reliability test using Cronbach Alpha Coefficient and Kuder Richardson formula 21 Method. Analysis of variance (ANOVA) was used in analysing the data. Results reveal that teachers' qualification and experience were significant. It is recommended that the study of learning disability should be included in the teacher training curriculum in private primary schools in Uyo Local Government to make teachers garner experience and expertise in handling special need children.

Keywords: Teachers, Academic Performance, ADHD, Learning Disability, Special Needs Children, Akwa Ibom

\section{Introduction}

The joy of every parent is to have their children performing excellently well in their school works. Academic achievement as a potent factor is the driving force of all stakeholders in the education sector. But this has been negated by the presence of Attention Deficit Hyperactivity Disorder (ADHD) which poses a serious risk of underachievement (Barkely, 1999) as they have difficulty in sitting and following through an instruction in the classroom and with the fact that the classroom is a structured environment, they find it difficult to easily adjust to the system.

Attention deficit hyperactivity disorder (ADHD) is characterised by inattention, hyperactivity, impulsivity, cognitive, behavioural and emotional deficits. ADHD is also closely related to learning disabilities, lack of self control, and social skill deficit (Egger and Kauchak, 2001).

Approximately half of ADHD children show symptoms by the time they are 5 years old, and begin to display behavioural problems during the early school years when they have to take instructions from teachers and obey school rules. ADHD children are reported to have problems with self control both at home and at school, to have a tendency to show aggressive behaviour, to suffer from low self esteem and lack of confidence, to display problems with underachievement, and to have learning disabilities (Barkley, 1999).

The school environment requires attention, sitting still, planning ahead, effective concentration and learning. These children forget assignments, often talk excessively and fidget; they find it difficult to follow through tasks and blurt out answers before questions are being completed.

Thus, attention deficit hyperactivity disordered pupils are often ignored, punished and given names by teachers. The teacher may not see it as a behavioural problem that affects learning rather attribute it to poor home training, laziness and irresponsibility. Teachers may resort to punishing and bullying pupils with traces of ADHD without necessarily understanding problems many of the pupils may be going through in the process of learning. In the school system, no provision has been made regarding intervention for pupils with ADHD. Since the knowledge of ADHD and how it influences academic performance, is not widely known, it is appropriate to conduct a study as to ascertain the differences between teachers' and pupils' factor and academic performance of pupils with ADHD. The teachers' variables of qualification and experience happens to serve as moderating variables in handling special need children (DarlingHammond, 2000) as it takes well-certified teachers in care of content areas of special education or learning disabilities to 
be able to meet the individual needs of those categories of children.

Also, teachers' experience gained on field either as undergraduate in teaching practice or post-university experience in the field of teaching are vital intervention for children with ADHD. Children with ADHD in primary two were selected as samples for the purpose of this study as they are mostly less than 7 years of age which is the age of onset of most learning disabilities.

\section{Statement of the Problem}

Attention Deficit Hyperactivity Disorder is one of the most commonly diagnosed childhood disorders. It is estimated that it is observed in three to five percent of school aged population (Small, 2003; Barkley, 1999). This implies that it affects about one student in every classroom. Thus, when ADHD is left unidentified, and managed, the cumulative effect will be low self esteem, poor peer relation and chronic school failure.

Though every child occasionally has difficulty sitting still or sustaining attention yet for some children the problem is no persistent and serious that it interferes with learning and relationships. It is common observation that these children have low attention span, which affects their coping ability in school. At school, they require differential treatment based on their needs to meet up with the school activities contrary to the expectation of serene school environment (Egbochukwu and Abikwi, 2007). Therefore, it is important to carry out a study on the differences between teachers factors and academic achievement of pupils with ADHD.

\section{Purpose of the Study}

This study is aimed at examining the teachers' factor as regards the academic performance of pupils with ADHD. Specifically the research would help to:

1. Find out the difference in the academic performance of pupil's taught by teachers with various levels of qualification;

2. Determine the difference in the academic performance of ADHD pupils taught by teachers with various levels of teaching experience.

\section{Research Questions}

The study was guided by the following research questions:

1. Is there a difference in the academic performance of pupils with ADHD taught by teachers with various levels of qualifications in private schools in Uyo Local Government Area?

2. Is there any difference in the academic performance of pupils with ADHD taught by teachers with various levels of teaching experience in private schools in Uyo Local Government Area?

\section{Research Hypotheses}

The following hypotheses were formulated to guide the study:

1. There is no significant difference in performance of pupils with ADHD taught by teachers with various levels of qualifications in private schools in Uyo L.G.A.

2. There is no significant difference in performance of pupils with ADHD taught by teachers with various levels of teaching experience in private schools in Uyo L.G.A.

\section{Significance of the Study}

The teacher, being the major transmitter of knowledge in the school system, will benefit from this research work immensely as it will open his eyes to the reality of ADHD in the classroom and dispel the myth in his heart about the kids as being troublesome and without home training. Thus, the teacher would be better equipped to manage effectively the behaviour of children with ADHD.

The pupils, being the beneficiary of learning will benefit from this research work as high teachers effectiveness consequently lead to high academic performance of pupils. Since their teachers are now aware of their challenge, they will be able to improve their academic performance. The policy makers and curriculum planners being the author of the 
framework of all the activities that guide teaching and learning in the classroom, will be able to adopt the finding of this research work for future policy making and curriculum draft especially for the inclusion of such findings in the teachers' training manual. This will further give them a sense of fulfilment for charting a workable plan of action.

School proprietors and administrators will also benefit immensely from this research work as the proper application of educational and behavioural intervention for pupils with ADHD will help to reduce pupils' failure and drop-out rate and consequently improve school enrolment. In conclusion, this research work will serve as a foundation for future in-depth researches that will be conducted on ADHD and pupils' performance.

\section{Delimitations of the Study}

This research work with an independent variable of Teachers' factors and dependent variables of academic performance of pupils with ADHD was delimited to pupils with attention deficit/hyperactivity disorder between ages 5 and 7 . This gives an average of age 6 as the America Psychiatric Association diagnostic age.

It is worthy to note that this is an expressive age where the children are not even conscious of their behaviour, hence, they act naturally. This age bracket falls in primary 2, and private schools in Uyo Local Government area was chosen as other performance indices are minimally controlled while academic performance took the areas of English, Mathematics and quantitative reasoning into consideration as these are subjects where individual applications of learned techniques and aptitude are required.

\section{Methodology}

The study was conducted in Uyo Local Government Area in Akwa Ibom using Expost facto survey research design because assignments of participants to levels of the independent variable is based on events that occurred in the past (i.e, after the fact). The population of the study consists of all the private primary schools and teachers in Uyo L.G.A while a total number of 92 pupils and 16 teachers were purposively selected from the randomly selected schools. This was due to the characterised nature of the sample under consideration as all pupils with a score of seven(7) and above are selected as pupils with ADHD. The instruments for data collection were ADHD Checklist and Aptitude test and they were face validated by 3 experts. The reliability coefficient of the instruments were ascertained using Cronbachs Alpha coefficient and Kudar Richardson 21 to arrive at a reliability coefficient index of .72 and 0.64 which shows that the instruments were highly reliable.

Mean and standard deviation were used to answer research questions while Analysis of Variance was used to test the hypothesis at 0.05 level of significance.

Results: Data were collected and analyzed with Analysis of Covariance (ANOVA).

\subsection{Hypothesis One}

There are no significant differences in the performances of pupils with ADHD taught by teachers with various levels of qualification in private schools in Uyo L.G.A.

Table 1A: Basic data of performance of pupils with ADHD taught by teachers with various levels of qualifications

\begin{tabular}{|l|c|c|c|}
\hline Details & $\mathrm{N}$ & $\sum$ & $\left(\sum \mathrm{x}\right)^{2}$ \\
\hline ADHD pupils taught by teachers who are graduates $\left(\mathrm{x}_{1}\right)$ & 25 & 1384.44 & 1916674.1 \\
\hline ADHD pupils taught by teachers who are NCE and OND holders $\left(\mathrm{x}_{2}\right)$ & 37 & 1174.16 & 1378651.7 \\
\hline ADHD pupils taught by teachers who have O'levels certificates $(\mathrm{X} 3)$ & 30 & 1147.47 & 1326687.4 \\
\hline Total & 92 & 3706.07 & \\
\hline
\end{tabular}

Table 1B: Analysis of variance of the difference in academic performance of pupils taught by teachers with various levels of qualifications in private schools in Uyo L.G.A

\begin{tabular}{|l|c|c|c|c|c|}
\hline Source of variation & SS & Df & Ms & F.cal & F. critical \\
\hline Between groups & 10739.35 & 2 & 5369.68 & \multirow{2}{*}{14.87} & 3.15 \\
\hline Within groups & 32133.9 & 89 & 361.06 & & \\
\hline
\end{tabular}


From Table 1B, it was observed that the calculated F-value of 14.87 is greater than the critical value of 3.15 at 0.05 level of significance. Thus, the null hypothesis which states that there is no significance difference in academic performance of pupils taught by teachers with various levels of qualifications in private schools in Uyo L.G.A is rejected. This means that the academic performance of pupils taught by teachers with various levels of qualification differ significantly in private schools in Uyo L.G.A.

\subsection{Hypothesis Two}

There is no significant difference in the academic performance of pupils with ADHD taught by teachers of various levels of teaching experiences in private schools in Uyo L.G. A.

Table 2A: Basic data on academic performance of ADHD pupils taught by teachers with various levels of teaching experience

\begin{tabular}{|l|c|c|c|}
\hline Details & $\mathrm{N}$ & $\sum$ & $\left(\sum \mathrm{x}\right)^{2}$ \\
\hline ADHD pupils taught by teachers with 10 years and above teaching experience $\left(\mathrm{x}_{1}\right)$ & 55 & 2490 & 628849 \\
\hline ADHD pupils taught by teachers with 5-10years teaching experience $\left(\mathrm{x}_{2}\right)$ & 10 & 423 & 178929 \\
\hline ADHD pupils taught by teachers with 0-5 years teaching experience $(\mathrm{x} 3)$ & 27 & 793 & 6200100 \\
\hline Total & 92 & 3737.04 & \\
\hline
\end{tabular}

Table 2B: Analysis of variance of the difference in the academic performance of pupils with ADHD taught by teachers with various levels of teaching experience in private schools in Uyo L.G.A

\begin{tabular}{l|l|c|c|c|c|c|}
\hline Source of variation & SS & Df & Ms & F.cal & F. critical \\
\hline Between groups & 8535.04 & 2 & 4267.52 & \multirow{2}{*}{9.93} & \multirow{2}{*}{3.15} \\
\hline Within groups & 38248.66 & 89 & 429.76 & \\
\hline
\end{tabular}

From Table 2B, it was observed that F-cal which is 9.93 is greater than F-critical of 3.15 at .05 level of significance. Thus, the null hypothesis, which states that there is no significance difference among the academic performances of pupils with ADHD taught by teachers with various levels of teaching experience is private schools in Uyo, L.G.A is rejected. This means that there exists a significant level of difference among pupils with ADHD taught by teachers with various levels of teaching experience in private schools in Uyo L.G.A.

\section{Discussion}

The finding of the study which states a non significant difference in the academic performance of pupils taught by teachers with various levels of teaching qualification was found to be significant. The implication is that pupils taught by highly certified teachers tend to perform better than their counterparts taught by teachers who are not highly qualified. The findings of this study were consistent with the findings of Reid, Eddy, Bank and Fetrow (1994) in their study they discovered that teachers who have undergone training in special education or learning disability were more confident in their ability to set up effective behaviour contracts and adjust lessons or materials for student with ADHD. This was also supported by Jerome, Gordon and Hustler (1994) study which found that amount of teachers' specific training in education and knowledge of hyperactivity highly influence their pupils' performance. Matlock (1999) also found out that teachers who have specific training were more likely to try various alternative educational interventions when all conventional methods of teaching are not productive thereby improving learning. Furthermore, Small (2003) found out that teachers with more training and those that developed themselves through self study on education have their students scoring higher.

Contrarily, Piccolo-Torsky and Waishwell (1998) found no significant influence of teachers' qualification on academic performance of pupils with ADHD. This was supported by Sciutto, Terjesen and Brender-Frank (2000) when they found out that academic performance of pupils with ADHD was unrelated to teachers' educational level but experience gained from teaching pupils with ADHD. In general, researchers have found that possessing a major or minor in subject matter is related to increased pupils achievement in the subject area. This suggests that greater subject matter knowledge is associated with gains in pupils' achievement. 
It was also revealed that there is a significant difference in the academic performance of pupils with ADHD taught by teachers with various levels of teaching experiences this was consistent with the findings of Ehrenberg and Brewer (1994) when they discovered that the teachers' experience was positively related to white and African American students' gain scores. This was also corroborated by Rowan, Corenti and Miller (2002) in their study of teachers' experience on pupils' achievement in elementary schools comprising of both ADHD and control group. They discovered a significant effect of teaching experience on pupils' achievement .Teachers with over ten years of teaching experience showed a reduced influence of ADHD on pupils performance as compared with teachers with years of experience below 10 years. But the finding of Monk (1994) was contrary. In his study, of high school Mathematics and Science teachers, he found out that teachers experience had no effect on student performance. In conclusion, the studies have been able to authenticate the influence of Teachers' variables of qualification and experience on academic performance of pupils with ADHD.

\section{Conclusion/ Recommendations}

From the research findings, the two hypotheses of Teachers qualification and teaching experiences were significant. Accordingly, it was concluded that teachers' qualification and teachers' years of teaching experience had a significant level of influence each on academic performance of pupils with ADHD in private schools in Uyo L.G.A. of Akwa Ibom State.

Based on the findings of this study, which has established a significant level of influence of teachers' factors on academic performance of pupils with ADHD in private schools in Uyo Local Government Area, as a means of bridging the missing gaps in the research area, it was recommended that teachers' educators should ensure that teachers should be both skilled and experienced in handling of special need children. This could be done by the inculcation of learning disabilities as a core course for all trainee-teachers at all levels.

\section{References}

Barkley, R. A. (1999) Young Adult Follow-up of Hyperactive Children: Antisocial Activities and Drug use. Journal of Child Psychology and Psychiatry, 45(2): 195-211.

Darling-Hammond, L. (2000) Reforming Teacher Preparation and Licensing: Debating the evidence. Teachers College Record, 102(1): 28-56.

Egbochuku, E. O. and Abikwi, M. I. (2007) The Prevalence of Attention Deficit/Hyperactivity Disorder (ADHD) Among Primary School Pupils. The Journal of Human Psychology, 22(4): 317-322

Egger, P. and Kauchak, D. (2001) Educational Psychology: Windows on Classroom (5th ed.). New Jersey: Merrill Prentice Hall.

Ebrenberg, R. G, and Brewer, D. J. (1994) Do School and Teacher Characteristic Matter? Evidence from High School and Beyond. Economics of Education Review, 13(1): 1-17.

Jerome, L., Gordon, M. and Hustler, P. (1994) A Comparison of American and Canadian Teachers' knowledge and Attitude towards Attention Deficit Hyperactivity Disorder. Paediatrics, 88: 560-567

Matlock, E. A. (1999) Differences in elementary school Teachers' Instructional Environment and Perceived Competence towards Children with Attention Deficit Hyperactivity Disorder as a Function of Attitudes towards Control Vessels Autonomy, Training and Experience. Unpublished Doctoral Dissertation, Oklahoma State University.

Monk, D. (1994) Subject Area Preparation of Secondary Mathematics and Science Teachers and Student Achievement. Economics of Education Review, 13 (2): 125-145.

Piccolo-Torsky, J. and Waishwall, L. (1998) Teachers' knowledge and Attitude Regarding Attention Deficit Disorder. ERS Spectral, 16(1): $36-40$.

Reid, J. B., Eddy, J. M., Bank, L. and Fetrow, R. (1994) Some Preliminary Findings from a Universal Prevention Program for Conduct Disorder. Paper presented at the fourth National Institute of Mental Health National Conference on Prevention Research, Washington D.C.

Rowan, B., Corenti, R. and Miller, R. (2002) What Large Scale Survey Research tells us about Teacher's Effect on Student Achievement. Insights from the Prospects Study of Elementary Schools. Teachers College Record: 104 (8): 1525-1567.

Scuitto, M. J., Terjesen, M. D. and Brender Frank, A. S. (2000) Teachers' knowledge and Misperceptions of Attention in Deficit/Hyperactivity Disorder. Psychology in the Schools, 37 (2): 115-122.

Small, S. (2003). Attention-Deficit Hyperactivity Disorder: General Education Elementary School Teacher's Knowledge, Training and Ratings of Acceptability of Interventions. Unpublished Masters Dissertation, University of South Florida, U.S.A. 


\section{APPENDIX 1}

Private Primary Schools in Uyo Local Government Area

\begin{tabular}{|c|c|c|c|}
\hline 1. & Christ The King Nursery/Primary School & Wellington Bassey Way & Urban \\
\hline 2. & Qua Iboe Church Nursery/Primary School & 168 Aka Road, Uyo & Urban \\
\hline 3. & Okonee Nursery/Primary School & Abak Road & Urban \\
\hline 4. & Nuco Nursery/Primary School & Udoette Street & Urban \\
\hline 5. & Victory Nursery/Primary School & 75 Udoumana Street & Urban \\
\hline 6. & New Word Nursery/Primary School & Uyo & \\
\hline 7. & St. Joseph's Nursery/Primary School & Anua & Sub-Urban \\
\hline 8. & Delight Nursery/Primary School & Abak Road & Urban \\
\hline 9. & Mercy International Nursery/Primary School & 38 Udoekong Street & Urban \\
\hline 10. & Kiddies Nursery/Primary School & 6 Akpan Etuk Street & Urban \\
\hline 11. & St. John's Nursery/Primary School & Akpa Ube Street & Urban \\
\hline 12. & Ndianabasi Nursery/Primary School & Ifa Ube Street & Sub-urban \\
\hline 13. & King's Nursery/Primary School & Ikot Okubo & Sub-urban \\
\hline 14. & Monef Kiddies Nursery/Primary School & 6 Ben Udo Street & Urban \\
\hline 15. & Christian Fellowship Nursery/Primary School & Idoro Obio & Sub-urban \\
\hline 16. & Success Nursery/Primary School & Aka Itiam Street & Sub-urban \\
\hline 17. & Evangel Nursery/Primary School & Aka Itiam Street & Sub-urban \\
\hline 18. & Qua Iboe Church Nursery/Primary School & Four Towns & Urban \\
\hline 19. & Ascension Nursery/Primary School & 90 Udo Umana Street & Urban \\
\hline 20. & $\begin{array}{l}\text { Prince and Peace Montessori Nursery/Primary } \\
\text { School }\end{array}$ & Anua & Sub-urban \\
\hline 21. & Emmasu Nursery/Primary School & Nung Obio Enang & \\
\hline 22. & Kings And Queens Nursery/Primary School & Ewet Housing Estate & Urban \\
\hline 23. & Salvation of the Nations Nursery/Primary School & 1 Imatan Street & \\
\hline 24. & Adiaha Obong Nursery/Primary School & 22 Aka Road/Osongama Estate & Urban \\
\hline 25. & City Nursery/Primary School & 188 Oron Road & Urban \\
\hline 26. & Ikpaisong Nursery/Primary School & Ikot Akpa & \\
\hline 27. & Enoabasi Nursery/Primary School & Nsukara Offot & Sub-urban \\
\hline 28. & Jesus Saves Nursery/Primary School & Ifa lkot Okpon & Sub-urban \\
\hline 29. & Apostolic Nursery/Primary School & 3 Atim Atakpo Street & Urban \\
\hline 30. & Redeemed Nursery/Primary School & 6 Ikono Ibom Street & \\
\hline 31. & Bishop Usanga Nursery/Primary School & Ediene Ikot Obio Imo & Sub-urban \\
\hline 32. & Aunty Grace Nursery/Primary School & Ibiaku Offot & Sub-urban \\
\hline 33. & St. Michael's Nursery/Primary School & Ikot Okubo Offot & Sub-urban \\
\hline 34. & University Staff School & University Of Uyo & Urban \\
\hline 35. & Christian Safeway Nursery/Primary School & Obio Offot & Sub-urban \\
\hline 36. & Arch. Bishop Usanga Nursery/Primary School & & \\
\hline 37. & Scripture Union Nursery/Primary School & 53 lkot Abasi Street & Urban \\
\hline 38. & Prince and Peace Primary School & Anua & Sub-urban \\
\hline 39. & Reward of Foundation Nursery School & 12 Obon Ukpo Street & Urban \\
\hline 40. & Royal Kiddies Special School & Mbiabong Etoi & Urban \\
\hline 41. & Neson Nursery/Primary School & 20 Ebong Umoh Itong Street & Urban \\
\hline 42. & Unwanaobong Nursery School & Aka-Itaim Street & Urban \\
\hline 43. & Ray Field Nursery School & Nsikak Eduock Street & Urban \\
\hline 44. & Christian Nursery School & Idoro Road & Sub-urban \\
\hline 45. & Loyola Nursery School & Oron Road & Urban \\
\hline 46. & Covenant Nursery School & Okon Essien Lane & Urban \\
\hline 47. & John Paul II Seminarium & 2 Dominic Utuk Avenue & Urban \\
\hline 48. & Guyongtti Primary School & Atan Street & Sub-urban \\
\hline 49. & The City of God Nursery/Primary School & Efiat Offot & \\
\hline 50. & Saint International Nursery/Primary School & Ikot Oku Ikono & Urban \\
\hline 51. & Graceland Nursery/Primary School & Off Nsikak Eduok Avenue & Sub-urban \\
\hline 52. & Aunty Bassey Nursery/Primary School & 1 Shlter Afrique Mbiabong & Sub-urban \\
\hline
\end{tabular}




\begin{tabular}{|c|c|c|c|}
\hline 53. & Godswill Nursery/Primary School & Atan Offot & Sub-urban \\
\hline 54. & Uwakmfonabasi Nursery/Primary School & Atan Offot & Sub-urban \\
\hline 55. & God's Lamp Nursery/Primary School & Obio Etoi & Sub-urban \\
\hline 56. & Tech. Kiddies School & Itiam Ikot Ebia & Sub-urban \\
\hline 57. & Grace of God International Nursery/Primary School & 36 Ntiedo Udosen Street & Urban \\
\hline 58. & Dove International Nursery/Primary School & Asong Ama-lkot Akpan & Urban \\
\hline 59. & Tropicana International Nursery/Primary School & Afaha Oku Village & Sub-urban \\
\hline 60. & University Arms Nursery School & $45 \mathrm{lkpa}$ Road & Urban \\
\hline 61. & Shammah Christian Nursery School & 1 Akpa Inyang Street & \\
\hline 62. & Diamond/God Nursery/Primary School & 140 Nwaniba Road & Urban \\
\hline 63. & Royal Christian Nursery/Primary School & Ekpri Nsukara & Sub-urban \\
\hline 64. & God's First Nursery/Primary School & Efiat Offot & Urban \\
\hline 65. & One God Academy School & No. 1 Kevin Lane Aka Road & Urban \\
\hline 66. & Estate Nursery/Primary School & 1a Uruan Street & Urban \\
\hline 67. & Qua Iboe Fellowship Nursery/Primary School & 112 Nwaniba Road, Ewet & Urban \\
\hline 68. & Jevic Nursery/Primary School & Iboko Street & Urban \\
\hline 69. & Christian Fellowship Nursery/Primary School & 28 Umoren Lane & Urban \\
\hline 70. & Christian Montessori Nursery/Primary School & 28 Nepa Line & Urban \\
\hline 71. & Alpha Nursery/Primary School & Akpa Etuk Street & Urban \\
\hline 72. & Uncle Emmanuel Children School & 149 Nwaniba Road & Urban \\
\hline 73. & Christian Youths Academy & Mbiabong Etoi & Sub-urban \\
\hline 74. & Excellence Nursery School & 11 Ekpot Ossom Street & \\
\hline 75. & Alpha Foundation Nursery/Primary School & Mbiabong Etoi & Sub-Urban \\
\hline 76. & Bidamee International Nursery/Primary School & Nepa Line Off Eda Street & Urban \\
\hline 77. & King Solomon School & Ben Udo Street & Urban \\
\hline 78. & Fulga Nursery/Primary School & Ikot Ambang & Urban \\
\hline 79. & Hillside International Nursery/Primary School & Oron Road & Urban \\
\hline 80 & the & Ef & 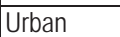 \\
\hline
\end{tabular}

\section{APPENDIX 2}

\section{Attention Deficit/Hyperactivity Disorder Checklist (Adhdc)}

Teachers Years of Teaching experience

\section{Below 5years $\quad-5$-10yrs 10yrs and above}

Teachers Qualification Graduate -------OND/NCE----------O'Levels-------

Tick the option that best answers the question to the child's school behaviour.

1. Fails to give close attention to details

2. Finds it difficult to finish home-work or any assignment

3. Makes careless mistakes in school works

4. Has difficulties in organizing tasks

5. Avoids, or is reluctant in engaging in tasks that entails serious reasoning Yes

6. Often loses necessary tools for academic work (pencil, pen etc) Yes

7. Is forgetful or absent minded in class

8. Often fidgets with hands or feet or squirms on seat

9. Often leaves seat in classroom to go outside

10. Climbs or jumps or play violently

11. Has difficulty playing or working quietly

12. Talks excessively

13. Hand writing is illegible and irregular

14. Blurts out answers before the questions have been completed

Yes

Yes

Yes

Yes

Yes

Yes

Yes

Yes

Yes

Yes

Yes

Yes

Yes

Yes

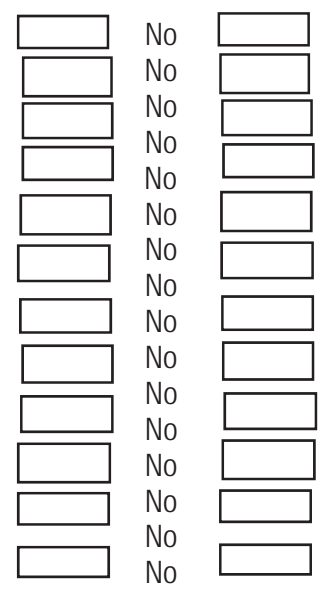

16. Disturbs or intrudes on others 


\section{APPENDIX 3}

\section{ADHD ACHIEVEMENT TEST}

I.D.

Write on the following topic

My Self

1.

\section{ADHD ACHIEVEMENT TEST}

I.D.

Write on the following topic

My Family

2.

\section{ADHD ACHIEVEMENT TEST}

\section{PRIMARY 2}

I.D.

GRAMMAR

Underline the Noun in the sentences below

e.g. Bola is sleeping
1. Uko has a book
2. That is my church
3. There will be joy in the morning
4. The chain is long
5. Jesus is my saviour

Underline the Adjective in the sentences below e.g. The rich man is back

6. The beautiful queen is dead

7. The wicked king was dethroned

8. The stone is hard

9. Our classroom is large

10. The man is kind

\section{Underline the verb}

e.g. Emem is jumping
11. Can you dance?
12. Let us pray
13. Have you read for the test?
14. Uko broke the glass
15. Print with us.

\section{ADHD ACHIEVEMENT TEST}

I.D. 
QUANTITATIVE REASONING

Write in a normal order. Smallest first. Example 19, $20,17,18,16=16,17,18,19,20$

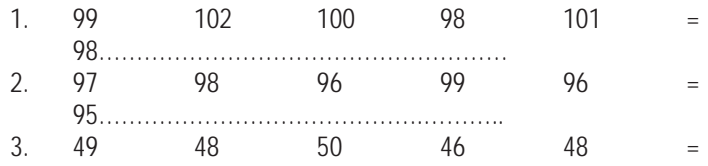

4. complete the following boxes. Follow the example

5.
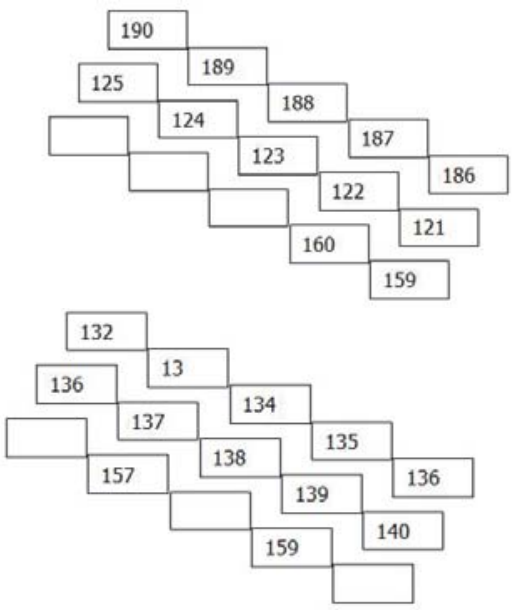

Put in the right order

$\begin{array}{llllll}\text { Example: } & 149 & 126 & 138 & 154 & 180 \\ & 126 & 138 & 149 & 154 & 180\end{array}$

6.

Example.

234

7.

\section{Example}

8.
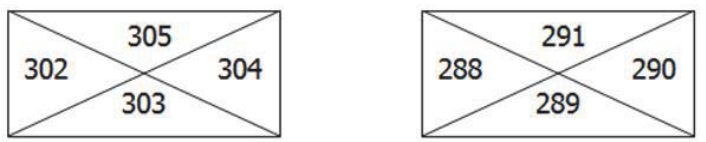

9.
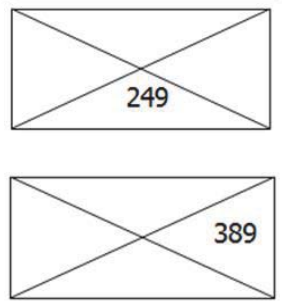
Example:
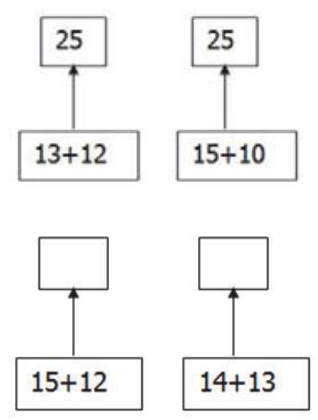

Example:

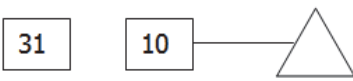

11.
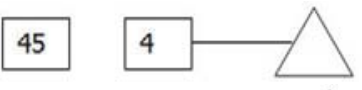

12.

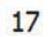

13

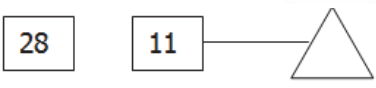

Circle and write out the biggest and the smallest number

\begin{tabular}{|c|c|c|c|c|c|c|}
\hline Example: 123 & 114 & 156 & 214 & 312 & $=$ & 312 \\
\hline 14. 133 & 397 & 214 & 137 & 60 & $=$ & \\
\hline 15. 126 & 304 & 217 & 87 & 320 & $=$ & \\
\hline
\end{tabular}

\section{ADHD ACHIEVEMENT TEST}

I.D.

\section{MATHEMATICS}

Instruction: answer all question

Fill in the missing space
1. 2
2. 5
3. 10
$\frac{10}{20}$
6
6

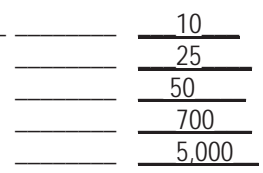
5. $\frac{300}{10000}$
6. Write in words
6. 100
7. 12,425 .
7. Write in figure
8. Seventeen thousand.
9. Ten.
10. Two Hundred.

Re-arrange in ascending order (from the lowest to the highest)

\begin{tabular}{|c|c|c|c|c|}
\hline \multirow[t]{3}{*}{ e.g. } & 102 & 902 & 402 & 607 \\
\hline & 102 & 402 & 607 & 902 \\
\hline & 106 & 1,105 & 118 & 2004 \\
\hline 12. & 200 & 100 & 300 & 500 \\
\hline
\end{tabular}

Arrange in descending order (from the highest to the lowest)

$\begin{array}{lllll}\text { e.g. } & 200 & 100 & 300 & 400\end{array}$ 


\begin{tabular}{|c|c|c|c|c|}
\hline & 400 & 300 & 200 & 100 \\
\hline 13. & 2 & 4 & 60 & 80 \\
\hline 14. & 30 & 40 & 108 & 107 \\
\hline
\end{tabular}

$3 / 4$ of 8 triangles $=$

16.

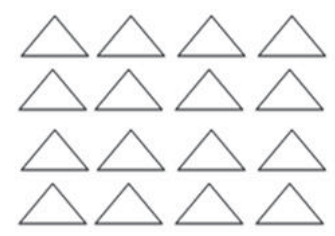

$4 / 5$ of 20 triangles $=$

Example: $19-1$ ten and 9 units

17. 284

18. 29

$$
=
$$
Tick $(\sqrt{ })$

Hundreds

......Hens

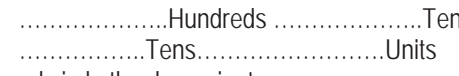

Tens

.Units

(5)

19. 3

8

Circle the even numbers

20. $1000 \quad 315 \quad 367$

21. $168177 \quad 165$

Underline the odd numbers

22. $781 \quad 892 \quad 250$

23. $2007 \quad 2002 \quad 2000$

24. (i) $\mathrm{H} \quad \mathrm{T} \quad \mathrm{U}$

$\begin{array}{lll}3 & 4 & 2 \\ -2 & 2 & 9\end{array}$

25. What is the time?

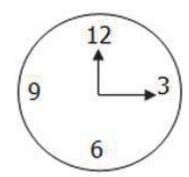


